\title{
Islamic mystical responses to hegemonic orthodoxy: the subcontinental perspective
}

\section{Setting the scene}

From the early thirteenth century down to the 1830s, Persian was the official language in major parts of the Indian subcontinent despite the fact that most common people could not read or write this classical language. Paradoxically, and despite its elite dimensions, as a linguistic and cultural phenomenon Persian posed a challenge to the hegemonic orthodoxy that revolved around Arabic, the language of religion (Islam). Indeed, the Sultans of Delhi, who were mostly of Turkic or Afghan origin (note that the Afghan language enjoys a striking similarity to Persian), realised the potential of Persian for use as a quasi-secular and flexible language. Later on, Akbar, the greatest Mughal Emperor (Mughals were originally Turks), also tried to check the ascendancy of ambitious Turks and the Arabic-knowing ulama (Muslim clergy) by patronising Persian. In this context, it is useful to remember that the Sufis who migrated to medieval India were primarily Turks and Persians. The Sufis were well versed in both Persian and Arabic but they mainly wrote in Persian and composed their Sufi music (Sama) in the same language, in order to make themselves intelligible to the ruling elite (both Muslims and non-Muslims), who knew Persian due to its role as the official language. This convergence of imperial and Islamic mystical endeavours marked the triumph of Persianate tradition, which represented heterogeneity, as opposed to the process of Arabisation, which is often associated with homogenising propensities (compare the Arabisation of North Africa with subcontinental Persianate traditions).

This paper aims to contextualise and analyse some leading Persian texts (such as Akhbar ul Akhyar, which appeared in the sixteenth century, and Safinat ul Awliya and Majma-ul-Bahrain, both from the seventeenth century) in order to explore elements of the implicit, and at times explicit, challenges posed to the hegemonic orthodoxy, which was often identified with the Arabisation process. We are not using the term Arabisation here exclusively in the linguistic sense. Rather, the term is used to represent a religious-cultural process with homogenising propensities that are contrasted with the Mughal cosmopolitanism associated with Persianate tradition. In the eighteenth century, with the decline of Mughal political power, we notice the resurgence of the hegemonic orthodoxy which launched its assault against the Persianate tradition and against aspects of 
the mystical traditions allegedly associated with it. Paradoxically, the assault was not exclusively exogenous, because some of the very products of the Persianate tradition, such as Shah Waliullah of Delhi, became critical of the tradition and gravitated towards reform based on 'Arabisation'. Such individuals believed that the Persianate tradition and aspects of the related mystical traditions contributed to the decline of Mughal political power and the degeneration of Muslim society throughout the subcontinent.

In the subcontinent, Friday prayers, centring around the mosques, are characterised by the overwhelming visibility of males. In other words, hegemonic orthodoxy is also represented by a form of masculinity. The gatherings in Sufi shrines, by contrast, are characterised by the presence of women and children, (both Muslims and non-Muslims) the marginalised elements in society. Indeed, mystical traditions often represent feminine dimensions in predominantly masculine cultures. Unlike the scripture- or mosque-based hegemonic orthodoxy, mystical traditions placed emphasis on the local symbols of Islam, such as the Sufi shrine, veneration of Sufi saints, pilgrimage to the local shrine (as if competing with the universal annual pilgrimage to Mecca), etc. In the Persian texts mentioned above (also known under the broad categories of tazkira, or Sufi hagiography, and malfuzat, or table talks involving a Sufi saint), we notice the representation of the mothers or daughters of illustrious Sufi saints as pious ladies. We also notice women acting as Sufis themselves (pirani). Many of these pious women are shown as possessing the power to perform miracles (keramat) or to shower blessings (Baraka) on their disciples. As a counterpart of the ulama (Male Muslim clergy), they were even entrusted with the sacred job of disseminating knowledge relating to ethics (Akhlaq literature) and right conduct or behaviour $(A d a b)$ among the masses. This newfound role for women in the practice of Muslim piety was unique and is an example of the individualisation of religious experience.

However, we should not exaggerate the role of this individualisation process as this experience was very much restricted to a small number of special women who occupied lofty positions in the mystical hierarchy and, hence, could easily be distinguished from ordinary women or the masses. The legitimising process involving these special women or spiritual elites is interesting. For example, their genealogy is often traced from the Sayyids, or the Prophet's family. Or at least they were depicted as the mothers, sisters, or daughters of illustrious male Sufis. In Weberian terms, these elite women enjoyed both hereditary and acquired charisma, which easily differentiated them from the masses of devotees. In the formation of this counter-hierarchical setup, which posed a challenge to the masculine hegemonic orthodoxy, we therefore notice a de-individualisation of religious experience. 


\section{Abdul Haq Muhaddis Dehlawi: a theologian Sufi or a Sufi theologian?}

Shaikh Abdul Haq Muhaddis Dehlawi (1551-1663) was one of the most illustrious scholar-sufis (alim-sufi) of Mughal India. He compiled Akhbar ul Akhiyar (in Persian), which is recognised as a leading source on South Asian Sufism. ${ }^{1}$ His name gives us a first insight into his life. We can see that he was based in Delhi (Dehlawi) and that he was well versed in hadis, for which he earned the title Muhaddis (someone learned in hadis). In spite of being based in Delhi, he was also an extensive traveller and travelled as far as Hijaz (Saudi Arabia) to study the hadis and Islamic law. In addition to being thoroughly exposed to Islamic scholarship, he was also initiated into various Sufi orders and it is for this reason that he is appropriately termed a scholar- (alim)-Sufi. This remarkable and charismatic scholar-Sufi needs to be studied in the context of his various entanglements, which were both religious and mundane in nature. We have discussed the fact that Abdul Haq was celebrated both as an alim (Muslim theologian) and a muhaddis (someone well-versed in hadis). These qualities enhanced his status among other Muslim scholars, some of whom were supporters of scriptural fundamentalism. Even during the Islamic revivalism of the eighteenth and nineteenth centuries, after his death, the reformists were unable to denounce him, despite his strong connections with the Sufis. Seen from this perspective, he enjoyed a unique position in South Asian Islam. In spite of his profound knowledge of Islamic theology, he was also interested in mystical experiences, which kept the door of religious individualisation open for him. Due to his reputation as an alim and muhaddis, he was not ostracised by the custodians of hegemonic orthodoxy for his inclination towards Islamic mysticism. His de-individualising qualities (a muhaddis-alim cannot easily be distanced from the sharia or the canon law of Islam) shielded him from potential danger. To confirm our hypothesis, we may cite the examples of the Mughal Prince Dara Shukoh and his close associate Sufi Shahid (Martyr) Sarmad, whose religious views had individualising potential. These men were executed by the Mughal State under Emperor Aurangzeb, who used their religious views as a pretext for their elimination. During their tragic deaths, we notice a convergence of hegemonic orthodoxy and hegemonic polity.

1 A copy of the Persian text is available at the Asiatic Society of Bengal. Abdul Haq was well versed in Fiqh (Islamic jurisprudence). Arthur Buehler, in his seminal work on Shaikh Ahmad Sirhindi, has used the term 'Jurisprudential Sufism', which is also applicable in the case of Abdul Haq, see Buehler 2011. 
Through the event of execution of Sufi Sarmad, Indian Sufis got their ideal martyr and he is regarded as the Mansur Hallaj of India. ${ }^{2}$

The linguistic dimension of Abdul Haq's religious individualisation also demands our attention. Like other theologians, Abdul Haq was well versed in the Arabic required for reading the written scripture. He could, then, have written about Sufis and Sufism in what is recognised by Muslims as the language of religion. The importance of the original language can be seen in the widespread resistance to attempts to translate the Quran from Arabic into any other language. The eighteenth century reformist Shah Waliullah of Delhi showed his guts and gumption when he became the first Indian to translate the entire Quran into Persian. Since Persian was the official language in the subcontinent, even Hindu nobles cum administrators had to learn it. The translation of the Holy Book into Persian thus gave educated non-Muslim Indians access to the Quran, which created a favourable environment for interfaith dialogue. This pioneering translation of the Holy Book had the potential to emancipate religious discourse related to Islam from the monopoly of the ulama and to incorporate multi-religious South Asian elements into the process of discourse. In this context, the eminent theologian Shah Waliullah emerged as an active agent of religious individualisation in eighteenth century South Asia. What about those scholar-Sufis (alim-Sufis) or Sufis involved in compiling the malfuzat (table talk involving Sufi saints), maktubat (letters exchanged between Sufi saints), and tazkiras (biographies of Sufi saints) in the Persian language from pre-Mughal times onwards? Since Sufism in the subcontinent had both Muslim and non-Muslim followers, and the educated among the latter read Persian, the situation was amenable to interfaith dialogue. This was a process that was not particularly attractive to the ulama, who were keen to establish the superiority of Islam in comparison to other religions. A section of the ulama in pre-Mughal India went so far as to express their views in favour of the forced conversion of non-Muslims. However, wise and farsighted Turko-

2 Mansur Hallaj was martyred for uttering the individualising words Anal Huq, meaning 'I am the Truth' or 'I am God'. Due to a mystical experience, he refused to differentiate himself from God. In short, only God prevailed in his successful mystical experience. For boldly uttering this truth, representatives of the hegemonic orthodoxy in West Asia cut him into pieces several centuries before Sufi Sarmad. From then on, all the persecuted Sufis argue that they are afraid of divulging the mystical Truth because their fate could be like that of Mansur Hallaj, who is recognised by the Sufis as one of the earliest martyrs in the history of Sufism. His plight is compared with the tragic battle of Karbala, during which the Prophet's grandson Husain attained martyrdom. Husain's death marks the beginning of a tradition of individuals regarded as the martyrs of love (for God). This category represents the highest form of religious individualisation in Sufism. Still, we must not overlook the political agenda behind the execution of the Mughal Prince Dara and his associate Sufi Sarmad. 
Afghan rulers such as Iltutmish dismissed proposals of this kind and aspired instead to counter the arrogant ulama with the Sufis, who represented a more liberal, human, spiritual, and to a great extent pragmatic, outlook in the context of challenges faced by the early Muslim empire builders in South Asia. ${ }^{3}$ While the Mughal and pre-Mughal Muslim rulers in South Asia played a significant role in promoting Persian as the official language or language of administration, at the socio-cultural level this classical language was virtually institutionalised by the various Sufi orders who used it to produce and circulate their religious manuscripts, as mentioned earlier. Largely because of this conscious selection of the 'other' (a language other than Arabic), Persian was able to flourish as an important vehicle for the spread of mystical knowledge in the subcontinent. This Persianisation also facilitated the democratisation of mystical knowledge, in the sense that Hindu nobility or administrators who knew Persian could now access Islamic texts. However, it is important to remember that this process of Persianisation, which elevated Sufi knowledge or mystical knowledge to the status of shared knowledge by incorporating the non-Muslims who knew Persian, fell short of truly domesticating mystical knowledge because Persian was not the language of the masses in India. ${ }^{4}$ Even the sama (sufi music) was composed in Persian. ${ }^{5}$

3 Nurul Hasan 2005, 67 and Rizvi 1986, 135f. Non-Muslims far outnumbered the Muslims in Medieval South Asia. The farsighted Muslim empire builders more or less followed a policy of non-interference as far as the belief pattern of non-Muslims was concerned, an approach that enhanced the legitimacy of those rulers. While a section of the ulama showed interest in conversion, the Sufis in general exhibited a liberal, human, and spiritual outlook, which sustained India's eclectic traditions. In order to gain greater acceptance among a heterogeneous population, the rulers in South Asia often patronised institutions, such as Sufism, which reflected multi-religiosity or multi-culturalism.

4 I have borrowed the term 'domestication' (of knowledge) from Rahul Parson's article on Banarasidas, which he wrote for the Erfurt Research Group (2013-2015). Arthur Buehler (2011), in his monumental work on Shaikh Ahmad Sirhindi, has shown that there were only 3\% of the entire population ruled by Emperor Akbar were ashraf (aristocratic Muslims who claimed foreign origin). So we can argue that the Persianisation of Sufi texts not only implied their democratisation but also their de-ashrafization, or the emancipation of mystical knowledge from the monopoly of the Arabic-speaking ashraf. It created a situation in which non-Muslims who knew Persian could also access knowledge related to Islamic mysticism.

5 As demonstrated by the famous medieval court poet Amir Khusru (d. 1325), who was the murid (disciple) of the illustrious Chishti Sufi saint Nizamuddin Awliya. Chishti is the name of the popular Sufi order that popularised Sufi music. The heterogeneity of Sufism is confirmed by the fact that the Naqshbandi and the Suhrawardi orders discouraged music. Interestingly, but not surprisingly, the bauls (philosophical folk singers of nineteenth and twentieth century Bengal) trace a spiritual connection with the music-loving Chishti Sufis. Hegemonic orthodoxy within Islam is opposed to poetry, philosophy, and music, and Sufi and folk poets have been the target of orthodox criticism. Recently, a statue of charismatic baul singer Lalan Shah was destroyed by 
In other words, the individualisation of religion in South Asia should be studied in the context of the convergence between the Islamic mystical tradition and the Persianate tradition. ${ }^{6}$ This is why the Islamic revivalist/reformist movements in eighteenth- and nineteenth-century South Asia launched their assaults against the Persianate tradition, for this tradition had, according to them, contributed to the degeneration of Islam, culminating in the political decline of Muslim states. ${ }^{7}$

Regarding the multiple entanglements of Abdul Haq, we need to remember that the entry point of his religious individualisation was actually his father who was intensely mystical. In spite of this, his father Shaikh Saifuddin prescribed for his son the sharia-tariqa trajectory, in line with the established tradition. ${ }^{8}$ To satisfy the spiritual urges of Abdul Haq, his father had him initiated into the Qadiriya Sufi order (silsilah), and Shaikh Musa, who was living permanently in the court of Emperor Akbar, became his murshid (spiritual guide). ${ }^{9}$ Some of the Qadiriya Sufis are extremely intriguing figures, with a number of them going so far as to even study the Vedas and Upanishads. ${ }^{10}$ It should be noted that Emperor Akbar's policy of sulh-i-qul or peace with all was actually introduced by the Qadiriyas in the pre-Akbaride period. In this context, it is worth recalling that Prince Dara Shukoh was also initiated into the Qadiriya order and that he ventured to translate the Upanishads into Persian. We have also mentioned Abdul Haq's murshid, who had strong connections with the Akbaride court, a bastion of religious experimentation in sixteenth century India. It appears that these multiple entanglements with the forces of religious pluralism played a significant role in making Abdul Haq's magnum opus Akhbar ul Akhiyar (which is an account of Sufi saints) a non-sectarian work. This particular feature also enhanced the authenticity of his work. Here, Abdul Haq, in spite of being an alim (theologian), stands apart not only from the sectarian ulama but also from sectarian Natha

the custodians of religious fundamentalism in Bangladesh. All these examples challenge Samuel Huntington's thesis of a 'Clash of Civilisations' and indicate that there is, rather, a clash within civilisation. This clash within represents the clash between liberal, spiritual, and mystical Islam, on the one side, and hegemonic orthodoxy or scriptural fundamentalism, on the other. The former sustains the forces of religious individualisation.

6 For a detailed discussion of the Persianate tradition in India, see Robinson 2001, chapter one. 7 Ibid.

8 Hanif 2000, 41-50. Sharia means the canon law of Islam and tariqa is the mystical path of the Sufis. The most illustrious Sufis of South Asia first mastered the sharia and then traversed the Sufi path or tariqa. For the sake of convenience, I have called this the sharia-tariqa trajectory. Abdul Haq Muhaddis Dehlawi was one of the greatest alim-Sufis of South Asia to have followed this trajectory.

9 Ibid.

10 Ibid. 
Panth and Siddha literature. Jain Hindi literature is also instructional and sectarian. ${ }^{11}$ Treading amongst these various orthodox traditions, Abdul Haq's stance was neutrality, not only in religious matters but in the case of imperial politics as well. ${ }^{12}$ In fact, he was too submerged in mystical experiences to be a sectarian. ${ }^{13}$ It is in the context of his intense inner mystical urge that we notice the dynamics of the individualisation of religion. In spite of his thorough exposure to sharia and scriptural Islam, he felt that it was important to transcend this frontier. Another important point that demands our attention is the evolution of the term murshid or spiritual preceptor. In the early phase of empire building in which Turkic sultans such as Iltutmish were involved, the term murshid faced many challenges, even within the Muslim community. During the thirteenth century, the ulama became particularly jealous about the increasing popularity of charismatic murshids such as Khwaja Qutbuddin Bakhtiyar Kaki. The ulama wanted to drive him out of Delhi but were unsuccessful due to the intervention of Sultan Iltutmish, who venerated the Sufi saint. ${ }^{14}$ Nevertheless, during the sixteenth and seventeenth centuries, when the heyday of the Mughals coincided with the lifetime of Abdal Haq, a murshid's position in society was reasonably consolidated. The murshid was, by that time, recognised as an alternative source of authority, a divergent voice in the wider society, if not a direct challenge to the ulama. We use the term 'wider society' because a murshid's position was not confined to a particular community. In the South Asian context a charismatic murshid might be venerated by Muslims, Hindus, and Sikhs alike. Therefore, the social base of the murshid could be broader than that of the ulama. Whereas the ulama represented a rigid, formal, and external form of religion by putting emphasis on the universal symbols of Islam such as Mecca, the place of pilgrimage, the Holy Book or the Quran, the hadis (sayings and deeds of the Prophet Muhammad), and the Prophet, the murshid emerged as the 'imaginaire ${ }^{15}$ Muslim who indulged in creativity and improvisation, reflecting his appropriating nature which culminated in the recognition of local symbols of Islam, such as the Sufi shrine or the

11 Rahul Parson discusses this in his article, mentioned in n. 4 above, by citing Ramachandra Shukla. In this context, one must also remember the disenchantment of Abdal Haq's father with the greedy and mundane ulama. See Hanif 2000, 41-9.

12 Hanif 2000, 41-9.

13 In the context of bhakti or Jain experiences, Rahul Parson calls this anubhaba (inner self experience).

14 Rizvi 1986, 3-8, 11f.

15 I have borrowed the term 'imaginaire Muslim' from the international workshop held in Raleigh, USA in 2002. The title of that workshop, organised by the Triangle South Asia Consortium, was 'The Work of the Imaginaire in South Asian Islam'. The term 'imaginare' implies someone who is creative and improvisational and hence capable of transcending the narrow confines of scriptures. 
murshid himself. The nature of Islam in South Asia has to be understood in the context of the subtle tension between the universal and local symbols of Islam. The appropriating and accommodating nature of the Sufis often borders on Indianness. For example, Muinuddin Chishti, the doyen of the Chishti order in India used to advise his followers: 'Develop river-like generosity, earth-like hospitality, and sun-like wisdom'. ${ }^{16}$ While uttering these words he was aware that river, earth, and sun are venerated by the people of India. In spite of being a pious Muslim, he had no difficulty in using idioms and symbols that were intelligible to the Indian people. In this way, in the early Sultanate era, he represented a shift from extra-territoriality to Indianness. Extra-territoriality characterised ashraf behaviour (that of aristocratic Muslims who claim foreign origin). Seen from this angle we can conclude that some Sufis were associated with the de-ashrafisation process. Individualisation of religion involved all these intriguing developments, which do not merely indicate the blossoming of the inner self but a creative and meaningful identification with local symbols and alternative ritual patterns (such as veneration of the murshid, pilgrimage to the sufi shrine, taking part in sama or Sufi musical ritual on the anniversary of a Sufi saint's death, known as urs in Sufi terminology, or considering the composing of maktubat, malfuzat, and tazkira as acts of piety) ${ }^{17}$ without formally renouncing the Islamic identity. The ulama led a group or a local community. The preaching of the ulama was instructional in the sense that he expected his followers to observe the basic tenets of Islam against the threat that those who did not would be punished by God on the Day of Judgement. Therefore, the God of the ulama was often God the punisher. ${ }^{18}$ But the Sufis project a different image of God. God to them is benign, loving, and forgiving. The Sufi is also known as wali (plural: awliya), or the friend of God, or even the lover of God. ${ }^{19}$ Instead of terrorising the Muslim masses through pamphleteering, the Sufis advise the common man to select carefully the kamil murshid, or

16 Cited in De 2004, 1-15.

17 In mainstream Islam memorisation of the entire Quran (the person who achieves this is respected in the community as hafiz), writing tafsir (commentary on the Quran), or copying the Quran in beautiful handwriting are regarded as pious acts. So the Sufis managed to develop a parallel sense of piety through the compilation of Sufi texts in a language other than Arabic.

18 Thanks to the utilisation of printing technology in India since the nineteenth century, we find hundreds of pamphlets or booklets in the vernacular languages, with a deliberate admixture of Arabic and Persian words, which were used to terrorise the Muslim masses and deter them from any deviation from the basic tenets of Islam. The ulama considered the pirs (murshids or spiritual guides) as a potential threat in terms of their capacity to influence the masses. The ulama often denounced the pirs as bhanda faqir (Bengali) or pseudo pirs. The instructional pamphlets circulated by the ulama were known as nasihatnama. See Dey 2006, chapters 2, 3 and 4.

19 Aquil 2017, chapters 1 and 2. 
perfect guide, in order to experience the mystical Truth. ${ }^{20}$ Thanks to the systematic and sustained efforts of the Sufis, the -pir-muridi (spiritual preceptor and disciple) relationship had been institutionalised within the Sufi movement. Thus, unlike the ulama who interacts with the local community or group, Sufis could enjoy a special interaction with a special disciple. The specially chosen spiritual successor of a murshid is called the khalifa or deputy. In short, all khalifas are murids (disciples) but all murids are not khalifas. All this points towards the creation by the Sufis of a counter hierarchy. We know that collective (community) is very important in Islamic identity. But the success of the Sufis lies in the fact that they could create a spiritual space for the individual within the broad framework of Islam. Of course, that space is perennially threatened by the custodians of hegemonic orthodoxy.

\section{Religious individualisation, Sufism and the discourse on women}

Many Muslim writers speak with contempt about the incapacity of women in religious matters and of their lack of intelligence and morals. ${ }^{21}$ An early writer says, 'The majority of women are lacking in religion and virtue and that which prevails in them is ignorance and evil desires'. ${ }^{22}$

However, Sufis were well aware of the positive aspects of womanhood. Some of the Quranic tales serve as beautiful illustrations of the role of women in religious life. The most famous example is that of Potiphat's wife, as told in Sura 12: this woman, completely lost in her love of Joseph, is a fine symbol of the enrapturing power of love, expressed by the mystic in the contemplation of divine beauty as revealed in the human form. It can even be said that Sufism was more favourable to the development of feminine activities than were other branches of Islam. ${ }^{23}$ The sympathy of the Prophet for women, and his four daughters in

\section{Dey 2006, chapter 4.}

21 In the discussion of this intriguing sub-theme, we shall rely heavily on the Persian Manuscript of Abdul Haq Dehlavi entitled Akhbarul Akhiyar. Dehlavi devoted one entire chapter in this manuscript to female Sufis, a rare gesture in the history of South Asian Sufism.

22 Abu Talib, Qutal-Qulub II, 238. Cited in Smith 1928, 133.

23 The persecution and, at times, the elimination of the Sufis during the last hundred years in West Asia, North Africa, Afghanistan, parts of Bangladesh, and Malaysia has often meant less freedom for women in the public space. The evolution of feminine attire in these regions, particularly during the last fifty or sixty years, is indicative of the attempt to restrict the visibility of women in public space. In the early 1970s it was hard to find women in the capital city 
particular, excluded the feeling of dejection so often found in medieval Christian monasticism. The veneration of Fatima in Shia circles is indicative of the important role assigned to the feminine element in Islamic religious life. ${ }^{24}$ Before Sufism arose, women were recognised as saints, including Amina, the mother of the Prophet, and Fatima, his daughter, who enjoy the veneration of all Muslims because of their relationship to Muhammad. ${ }^{25}$ So it is not surprising that Shaikh Abdul-Haq Muhaddis Dihlawi (1551-1642) devotes a separate chapter to women saints in his famous Persian work, the Akhbaru'l-Akhyar. ${ }^{26}$ Being an expert on hadis (the recorded sayings and deeds of the Prophet), Abdul Haq knew the importance of the leading women in the family of the Prophet. The question is why most other writers were silent about the role of women in religion? This was because discussions about Muslim women in the public space were simply not common. Getting entry into the manuscript implied entry into the public space in one form because the manuscript could move from hand to hand. Veneration of the women in the Prophet's family is not only common in hadis, in sirat (biographies of the Prophet) literature too we find these women treated with respect. So, in the genre of Sufi literature, Abdul Haq's treatment of the topic was pioneering and bold. He did not want to end his responsibility just by mentioning them. If we carefully read his chapter on women Sufis, ${ }^{27}$ it is impossible to miss the degree of enthusiasm on the part of the pioneer author. Silently but clearly, Abdul Haq aspires to convey the serious message to the readers that women could acquire mystic-spiritual knowledge and that under such circumstances they should be elevated in the spiritual hierarchy just as their male counterparts were. This argument climaxes when citing an example he is allegorically posing a question before the audience/readers: 'Is not the lioness dreadful?? ${ }^{28}$ Given such a context, it is reasonable to propose that the production and circulation of Sufi texts (in

of Dhaka covering their heads but this practice is now quite common in many parts of West Bengal. In March 2017, I interviewed two highly qualified Bangladeshi ladies domiciled in the Western world. Both covered their heads and strongly opposed Sufism as a deviation. One of them would not allow her close relatives to sing before strangers under normal circumstances. One of the reasons underlying their dislike for the Sufis is the latter's fondness for sama or Sufi music, currently known as qawwali. However, we should remember that the Suhrawardiya and the Naqshbandiya Sufi orders do not encourage music. The Chishtiya order encourages sama.

24 Schimmel 1975, 426.

25 Smith 1928, 137.

26 Dehlavi 1605 (?), 280-3.

27 Edward Said, in his Culture And Imperialism, would call it 'reading between lines'. See Said 1993.

28 For the exact words, please see the next footnote. The Sufis used to respond to queries indirectly and in an allegorical manner. This apparently camouflaged the process of religious individualisation, making them immune to the assault of the custodians of hegemonic orthodoxy. 
Persian) in medieval India institutionalised the allegorical responses of the Sufi masters (murshids). The pattern not only betrayed their sense of humour but was crucial to the enhancement of their charisma among their followers, much to the consternation of the ulama. ${ }^{29}$

In fact, women continued to play an important role in the Sufi movement in India, both as Sufis and as mothers of leading Sufis. Shaikh Nizamu'd-Din Auliya used to say:

When the lion emerges from a jungle, none raises a question about its sex. The descendants of Adam should adopt piety and obedience to God whether they be men or women. ${ }^{30}$

It is instructive to consider the role of mothers in Sufi biographies. Many religious leaders admitted that they received their first religious instruction, and even their preliminary training in the mystical path, from their mothers. The Prophet said: 'Paradise lies at the feet of the mother'.

Whether it be Baba Fariduddin, Ganj-i Shakar's mother, or Shaikh Nizamu'dDin Auliya's mother, there is no doubt that many elderly women contributed to the spiritual formation of some of the great Sufi saints through their familial ties.

Bibi Sara is one of the earliest women saints mentioned in the Akhbaru'lAkhyar. She was the mother of Shaikh Nizamu'd-Din Abu'l Mu'id, an important contemporary of Khwaja Qutbu'd-Din Bakhtiyar Kaki. The Akhbaru'l-Akhiyar (in Persian) provides an interesting story involving Bibi Sara. People used to visit Shaikh Nizamu'd- Din Abu'l Mu'id to get rid of their problems, both spiritual and material. On one occasion, there was a drought (imsake baran) in Delhi. Everybody began to pray for rain (baran) and the Shaikh was requested to do likewise. The Shaikh then took a thread (rishla) from a garment (daman) worn by his mother. He held it in his hand and began to pray: 'Oh God the chastity (hurmat) of my mother is well-known. She has never unveiled her face before strangers, and I am praying on behalf of this pious lady, please send rain for us'. 'Az Shaikh in haraf guftan, az Khuda baran ferestadan' - After hearing the Shaikh's appeal God sent rain for them. ${ }^{31}$

Shaikh Abdul Haq Dihlawi clearly mentions the name of Bibi Zulaykha, the venerated mother of Shaikh Nizamu'd-Din Auliya: 'Bibi Zulaykha walida-e Shaikh

29 In the South Asian context, the ulama represents rigid, formal religion, and are not necessarily known for their sense of humour. On the contrary, the Sufis are known for their smiling image, their sense of humour, which is often associated with their spiritual wisdom.

30 Abdu'l Haqq, Akhbar, 280: 'Sher az bisha birun ayed kase pursid ke an sher nar ast va mada farzandane Adam ra ta 'at wa taqwae baid khua mard bashad wa khua zan.'

31 Dehlavi 1605 (?), 280. 
Nizamu'd-Din Auliya ast'. ${ }^{32}$ Nizamu'd-Din Auliya had deep respect for his mother. He used to say: 'Walida mara ba Khuda Ta'ala asna'i bud', ${ }^{33}$ - 'My mother was the way towards the Kingdom of God'. When the Shaikh's mother was faced with any problem, she could discover the solution in her dreams. According to Sufi belief, such a power was exclusively reserved for Sufi saints. In this context, it is not difficult to form an impression of her place (maqam) in the history of Sufism. Shaikh Nizamu'd-Din had to pass his early days in poverty. When the house was bereft of food (ghalla) his mother consoled him by saying that: 'Imroz ma mehman-e Khudayem'34 - 'Today we are the guests of God'.

One day, in a similar situation, the Shaikh's mother uttered these words and suddenly the Shaikh observed that a man appeared in front of their house with foodstuffs (ghalla) worth one tanka (silver coin). This experience brought about enough spiritual satisfaction to the Shaikh. Later on, whenever he was in a time of need (har hajati), the Shaikh would visit his mother's grave (khake walidai-e khud) and offer prayers. ${ }^{35}$

We have already referred to the ziyarat (religious visitation) of Shaikh Nizamu'dDin Auliya to his mother's tomb. In this connection, the Akhbaru'-Akhyar provides interesting information, the importance of which cannot be ignored if we are to come to a better understanding of the nature of relationship between the state and Sufism. Sultan Qutbu'd-Din Mubarak Shah (1316-1320) was jealous of Shaikh Nizamuddin's popularity and expected that, along with all the Shaikhs and Ulama, Shaikh Nizamu'd-Din should also visit the mosque in the fort of Sipri (qilae Sipri) for the Friday (juma) prayer. But the Shaikh replied: 'Masjid nazdik darem wa in ahaqq ast' ${ }^{36}$ 'There is a mosque nearby, and it is more worthy'. Now according to the Sultan's order, the entire religious community of Delhi assembled at the palace on the first day of the lunar month (darghurra har mahi) to offer congratulations (tahni-at) to him. The Shaikh further antagonised the Sultan by sending a loyal servant (iqbal-e khadim) as his deputy. The vainglorious Sultan (gharur-e badshahi) made it clear to the Shaikh that if he failed to pay homage to the Sultan in person, he would be forced to do so. Ignoring the threat, the Shaikh quietly prayed at his mother's tomb and returned home. Divine dispensation (qaza'i Ilahi) led to the assassination of the Sultan by his favourite and protégé Khusraw Khan before the first day of the next month (ghurra mahe ayanda) and

32 Ibid. 'Bibi Zuleikha is the mother of Shaikh Nizamuddin Awliya'.

33 Ibid.

34 Ibid.

35 Ibid.

36 Dehlavi 1605 (?), 282. 
the Shaikh was saved from humiliation. ${ }^{37}$ Thus the mother of Shaikh Nizamu'dDin not only contributed significantly to the later brilliance of her son but, even after her death, continued to remain a constant source of peace, solace, and inspiration to the greatest fourteenth century Sufi (d. 1325) in India.

So we notice that not only the murshids (spiritual guides) but also their pious mothers were presented as an alternative source of religious authority, perhaps as a plot to take the wind from the sails of the mullahs (ulama).$^{38}$ This representation also served another purpose. By projecting stories in which the pious mothers played a pivotal role, such those mentioned above, people were advised to respect their parents and their mothers in particular. In this way, the Sufis virtually institutionalised akhlaq (ethical) literature in medieval South Asia. This genre emerged as a parallel literature, if not the direct counterpart of the scriptures.

Another great woman Sufi was Bibi Fatima Sam of Delhi. Baba Farid (d. 1265) often referred to her piety and sanctity. Her spiritual qualities were equal to those of the greatest male Sufis of her time. It was for this reason that Baba Farid used to say: 'Fatima Sam marde ast'. ${ }^{39}$ She regarded Baba Farid and his brother, Shaikh Najibu'd-Din Mutwakkil, as her own brothers. ${ }^{40}$ Some important information about Bibi Fatima can be found in the malfuzat (conversations or discourses) ${ }^{41}$ of Shaikh Nizamu'd-Din Auliya (1238 - 1325). The Shaikh heard her saying: 'Az berai anke para'e nan wa kuza 'e ab bakase dehand neyamathaye dine wa duniya wai nisar'e yu kunand ke sad hazar roza wa namaz na' tuwan yaft'. ${ }^{42}$ This implied that feeding the hungry, giving water to the thirsty, and distributing money amongst the poor on festive occasions, were more meritorious than hundreds and thousands of namazes

37 Ibid. 282f.

38 Envisaging parents as substitutes for gurus is not uncommon in South Asia. In the 1970s, hundreds of thousands of people travelled to Western Bengal due to the Liberation war in Bangladesh, coupled with political turmoil and the related economic crisis. Under such circumstances, many people or families sought the intercession of gurus or so called religious guides. Some of those who refused to follow this practice stated 'we do not need gurus, parents are our greatest gurus'.

39 Ibid. 280: 'Fatima Sam is a man.'

40 In the conservative society of South Asia, it is very uncommon for a Muslim lady to treat men who are not her blood relatives as her own brothers. Fatima Sam's decision to do so reflects her independent spirit or man-like nature.

41 The discourses delivered by a leading Sufi to a select gathering of Sufi disciples and visitors gave rise to a distinctive genre of Persian literature. This was known as malfuzat, which also contained didactic poetry, anecdotes, and pithy sayings. For more information on malfuzat, see Rizvi 1986, 3-8 and 11f.

42 Abdul Haq, Akhbar, 280. 
(prayers) and many days spent in fasting (roza). Here, an independent spirit found expression through the criticism of rigid, formal, or external religion. Emphasis was explicitly placed on the humane aspect of religion. After her death, Shaikh Nizamu'd-Din Auliya used to go to his mother's tomb (rauza) to offer prayers and he always received spiritual satisfaction in doing so: 'Sultan-ul-Mashaikh (Shaikh Nizamu'd-Din) dar rauzae Fatima Sam bisiyar mushghul bude'. ${ }^{43}$ Again this is very significant. The great saint, instead of always visiting the mosque filled with devout Muslims, at times would seek spiritual satisfaction in the solitude of the graveyard. Indeed, the act of visiting the majar (grave) has been institutionalised by the Sufis. The Wahhabis ${ }^{44}$ are vehemently opposed to such practices.

The Chishti attitude to manual labour and prayer comes through clearly in a story related by the Shaikh.

One day the Shaikh visited the tomb of Bibi Sam, which was near a pond (hauz). A man appeared with a basket filled with khiyar (a vegetable resembling a cucumber) and dropped them near the tank, where he performed wazu (ablution) and then calmly said his prayers (du rakat-namaz). After that, he washed the khiyars one by one (yagan yagan khiyare shust) and then recited three blessings for the Prophet Muhammad. Being deeply impressed with the man's piety, the Shaikh offered him a silver tanka (coin) but this was refused. The Shaikh asked the man, who was a lowly paid labourer, how he could afford to refuse the offer. The man replied that his father was also a vegetable seller who died leaving him very young. After that, his mother was able to teach him the most elementary rules for formal prayers. When she was dying, she advised him: "Tu niz khiyare wa sabze ba-faroshi" - "You should also continue as a vegetable seller." In short, his dying mother instructed him not to depend on anything or anyone else for his living. ${ }^{45}$

After the man stopped talking, it appeared to the Shaikh as if he was listening to the words of a saint (awaze abdal ast). So manual labour was not looked down upon by the Chishtis. On the contrary, they were prepared to appreciate the qualities of a common man or woman if he or she was aware of the value of self-reliance and followed some basic rules for formal prayers. This was one of the reasons for the popularity of the Chishti silsilah (order) among the common people. Unlike the vainglorious and greedy ulama, ${ }^{46}$ the Chishti Sufis aspired

43 Ibid. 280. Sultanul-Mashaikh means 'king of the saints'. Mashaikh is the plural form of Shaikh (saint). The conscious borrowing of the political term sultan (king) seems significant for it poses a challenge to temporal authority.

44 For the sake of convenience, I have used this term, meaning, rigid, orthodox, and often militant Muslims, or self-appointed Muslim reformers.

45 Hamid Qalandar, Khayrul Majalis 227-78. Also see Abdul-Haq, Akhbar, 281.

46 Eighteenth century Punjabi Sufi poet Bullhe Shah's compositions are replete with such images of the ulama. 
to move closer to the everyday life of the common people and by emphasising the dignity of the common man, they reflected their de-ashrafising approach to society, very much in tune with the hadis. ${ }^{47}$

It is evident from the malfuzat (conversations or discourses) of Shaikh Nizamu'd-Din Auliya that the nazms (verses) of Bibi Fatima Sam were of exquisite beauty, delicate but full of spiritual thought. Shaikh Nizamu'd-Din had memorised a famous misra (hemistich) composed by her: 'Ham ishq talab kuni wa ham jan khuahi, har du talbi wale mir nashawad'48 - 'A person, who is a seeker of "Divine Love" (ishqe ilahi), but at the same time concerned with the safety and security of his personal life, cannot become a true lover'. Religious individualisation acquires a new dimension here with the differentiation between Divine Love (ishqe ilahi) and human love (ishqe majazi).

Bibi Fatima's tomb was in the old Indraprastha. After many years, it became a deserted place (kharabah). The memory of Bibi Fatima also fell into obscurity and she became known to the local people only as Bibi Saima or Bibi Sham.$^{49}$ From the perspective of religious individualisation, this geographical isolation of her grave is symbolic.

Shaikh Abdul Haq Muhaddis Dihlawi mentions the name of Bibi Auliya, a female Sufi who lived at the time of Sultan Muhammad bin Tughluq. Shaikh Abdul-Haq says 'Bibi Auliya az salihat waqte khud bud'50 - 'Bibi Auliya was one of the most pious ladies of her time'. She led a withdrawn life (khalwat) meditating in her hujra (chamber) for untold hours. She was also known for constant fasting. However, her reclusive life did not make her indifferent to the sorrows and sufferings of the common people. In the month of Muharram she actively engaged herself in charitable works which included the establishment of a langar (an alms house) for the distribution of free food among the poor. It is said that Sultan Muhammad bin Tughluq had deep faith in her. ${ }^{51}$ Shaikh Abdul-Haq wrote, 'Qabre wu birun qulae Alai ast ${ }^{52}$ - 'Her grave is situated outside the fort of Sultan Alau'd-Din Khalji (Ala'i)'. Her sons and grandsons apparently also became saints. When Shaikh Abdul Haq Muhaddis Dihlawi (1551 - 1642) was writing his Akhbarul-Akhyar, the descendants of Bibi Auliya were still alive and they were

47 The Chishti Sufis, in particular, wanted to get rid of the infamous ashraf (high born Muslims of foreign origin)-ajlaf (converted Indian Muslims) divide in Indian society. I have called this the de-ashrafisation process.

48 Abdul Haq, Akhbar, 280.

49 Ibid. 281.

50 Ibid. 283.

51 Ibid. 283.

52 Ibid. 283. 
popularly called himams (high-minded). ${ }^{53}$ Among them, Shaikh Ahmad probably became the most famous. He was also well informed about many Sufi saints. ${ }^{54}$

\section{Mughal prince Dara Shukoh and individualisation of religion}

Eclectic traditions both pre-existed and outlived the scholar cum mystic Prince Dara Shukoh. In this context, it will be useful to discuss the Sufi doctrine of Wahdat - ul - wajud or pantheism, which can be regarded as the entry point for the individualisation of religion in the Islamic mystical context. The Sufis use the term 'Hama Ust', meaning everything is 'He', which implies that God is reflected in everything. Using this doctrine some Sufis went so far as to claim that God is also reflected in a heathen or a Hindu and, given this, a Hindu cannot be denounced as a kafir or infidel. ${ }^{55}$ Mulla Daud, the author of Chandayan, who was linked to the famous fourteenth century Sufi Nasiruddin Chiragh-i-Delhi, praised Muhammad as the beloved of everyone. At the same time, he referred to the Vedas and Puranas as revealed books, like the Quran. ${ }^{56}$ Mirza Mazhar Jan-iJanan, a Sufi poet of the Naqshbandi order, came to the same conclusion as Dara, viz. that the Vedas were revealed books and Hindus could not thus be identified with the Kafirs of Arabia. He even argued that there was little difference between idol worship and tasawwar-i-shaikh (common among those who venerate a Sufi saint) or concentration on the mental image of the preceptor. ${ }^{57}$

Dara was a sound scholar, poet, and calligrapher with an artistic bent. However, unlike his great forefather Akbar, he was not adept in the art of statecraft. It is said that Emperor Shah Jahan advised his eldest son Dara to acquire the knowledge available in the Greek, Roman and Persian worlds alongside the knowledge prevalent in India. After completing this process, Dara should, according to his father, launch his career like a second Alexander (Sikander Sani). However, it was not Dara's desire to be another conqueror; he wanted instead to be a thinker. ${ }^{58}$ It appears from his famous work Majma-ul-Bahrain

\section{Ibid.}

54 Abdul-Haq, Akhbar, 283.

55 Hughes 1999, see Wahdat-ul-Wajud. Also, Chandra 1996. While the ulama is interested in proselytising, the Sufis are interested in the spread of love for each and every human being.

56 Chandra 1996, 139.

57 Ibid, cited on page 151.

58 De 1983, 294. 
that he believed in Ijtihad, or the right of the learned to interpret scriptures according to changing circumstances. In other words, he put emphasis on Aql, or reason, like his predecessor Akbar and his cultural successor Raja Rammohun Roy. The clash here is not, in fact, between different civilizations or languages but, rather, it is within Islam itself, between Ilm (here the term Ilm or knowledge has been used in a narrow sense, meaning scriptural knowledge) and Aql (Reason). The door of Ijtihad being partly closed, Aql (Reason) appears to have taken a back seat within Islam. But, till the tenth century, when the Mutazila (rationalist school) was still around, the term Ilm was used in the broad sense as it allowed Aql (Reason) to be its integral part. Through different phases, spanning several centuries, Islam experienced the reassertion of orthodoxy, which reduced the term ilm virtually to the status of literal fundamentalism or scripturalism. The eminent historian Muzaffar Alam has implied in his scholarly work that with the advent of western political dominance from the late eighteenth century, the nervousness of the ulama increased and they renounced and denounced the spirit of experimentation which had originally made Islam a world religion. In this way, the door of ijtihad (the right of the learned to interpret scriptures) was partly closed during the colonial milieu, culminating in the decline of $A q l$ (Reason) in Islamic societies. ${ }^{59}$ A majority of Muslim theologians still believe that if experimentation is allowed to continue then Islam could be overwhelmed by the 'other'. This situation poses a serious threat to India's eclectic traditions, which are intrinsically interweaved with the dynamics of religious individualisation.

Dara was only twenty-five when he produced his very first work in Persian, entitled Safinat-ul-Awliya (The Notebook of The Saints). He mentions in the introduction to this work that he used to venerate the Sufis and the religious divines. He had studied their lives closely but was disappointed to find that the details of their lives were scattered in the pages of so many different manuscripts, so he decided to produce this work in order to provide, within a very small canvas, the details regarding the dates of birth and death, the places of burial, and other important particulars of the saints of Islam. ${ }^{60}$ Without being sectarian, Dara wrote in this book about various Sufi orders. However, the most significant part of this work is the author's focus on women, as he deals with the wives and daughters of the Prophet and with a number of female mystics.

59 Alam 2004, 20-51.

60 Majma-ul-Bahrain by Dara Shukoh, edited in the original Persian with English Translation, Notes and Variants by M. Mahfuz-ul-Haq. The Asiatic Society. Kolkata, first published 1929, reprinted in 1982, 5. 
Bikrama Jit Hasrat, in his scholarly work Dara Shukoh: Life and Works (1979, reprinted 1982), has shown that Dara was not only respectful to female mystics but was also in favour of his talented sister Jahanara acquiring spiritual knowledge (see also, Dey 1996, 1-20). In Majma-ul-Bahrain, there is clear evidence to prove that Dara acquired knowledge about Tauhid (monotheism) and Irfan (divine knowledge). The latter is a Quranic word and the selection of such a word by Dara is significant but not surprising. Dara did not renounce Islam officially. However, his rivals tried to denounce him as an infidel, which served their narrow political interest.

Dara's Sanskrit learning enabled him to explore and appreciate Upanishadic monotheism, which was, according to him, no different than Quranic monotheism. From 1065 A.H. (?) onwards, he was more deeply interested in the study of Hinduism. In 1066 A. H. he had the Jug Bashist translated into Persian. Shortly after, he himself translated the Upanishads into Persian prose. He also most likely had one of his courtiers translate the Bhagvat Gita (Majma, 28).

In his Hasanat-ul-Arifin, which he completed in 1064 A. H., Dara included the name of Baba Lal - the only Hindu whose aphorisms he quoted. Dara also includes the name of this saint, whom he calls Baba Lal Bairagi, in the Majma-ul-Bahrain (Majma, 24), alongside those Muslim saints and divines who were the best representatives of Islamic mysticism. The inclusion of the name of a Hindu in such an exclusive list of Muslim divines shows unmistakably the high esteem in which this devotee was held by Dara. Indeed, Dara invited the saint to meet and had conversations with him. It appears that Dara's private secretary, Chandar Bhan, was present on the occasion of these interviews and, perhaps, acted as an interpreter (Majma, 24). It is useful to note that Dara's eclectic mind was so broad that he did not confine his efforts to exploring the commonalities between Hinduism and Islam only. He also thought about including other religions in his project, such as Christianity. This inclination was manifested in the year 1640-1641, when he carefully studied the Bible (see De 1983, 294).

We can wind up the discussion by considering a few examples from the Majma. This book begins with an interesting verse: 'Faith and Infidelity, both are galloping on the way towards Him [...]'. 'Apparently Abul Fazl had this verse inscribed on a building which Akbar had built for the common use of the Hindus and the Muslims' (Majma, 37). This was a clear manifestation of the fact that Dara derived inspiration from the eclectic spirit, which was sustained and enhanced by the policy put into action by his great grandfather. In the pages of Majma (38), Dara portrayed himself as a faqir endowed with esoteric knowledge (llm-I-Batin) with which he aspired to know the tenets of religion of the Indian monotheists. Dara was elated to find that the difference between Indian monotheism and Islamic monotheism was only verbal. 


\section{Significance of the endeavour and concluding remarks}

In religious individualisation, the power to select or reject a topic or to differentiate between topics according to their relative importance is crucial. All the topics in a religious text or religious tradition may be known to the practitioners of the religion. But in a particular socio-economic or political context, one or a few of them might assume a special significance. The charismatic theologian Sufi Abdul Haq successfully exercised that capacity to identify issues according to their relevance.

Symbols, idioms, terms, allegories, and particular short sentences can be extremely significant in Sufism. These assume a special meaning when we aspire to study religious individualisation. We can develop a method of negotiating Persian mystical texts. Like joining the dots, we may endeavour to link the symbols, idioms, terms, allegories, and particular short sentences dealing with a specific issue. For example, we can apply this method to Abdul Haq's narration of the life and philosophy of Bibi Auliya, a female Sufi. We instantly realise that this approach enriches our understanding of the dynamics of religious individualisation as they relate to a great woman Sufi, becoming more comprehensive and meaningful. On this particular occasion, we have linked 'Bibi Auliya az salihat waqte khud bud' - 'Bibi Auliya was one of the most pious ladies of her time'. She led a life spent in withdrawal (khalwat), meditating in her hujra (chamber) for untold hours. She was also known for constant fasting. In the month of Muharram, she actively engaged herself in charitable works, which included the establishment of a langar (an alms house) for the distribution of free food among the poor. It is said that Sultan Muhammad bin Tughluq had deep faith on her Shaikh Abdul-Haq wrote 'Qabre wu birun qulae Alai ast.' - 'Her (Bibi Auliya) grave is situated outside the fort of Sultan Alau'd-Din Khalji (Ala'i)' ${ }^{61}$

Regarding the comparison between the homogenising Arabisation of North Africa and the heterogeneous Persianate tradition of South Asia, I would like to mention a meeting that occurred while I was attending a programme on religious

61 The italicized terms or words confirm her exclusive and elevated position in the hierarchy of Sufis. The woman Sufi preferred to carry out her charitable works during the month of Muharram, which is significant. Because Husain, the beloved grandson of the Prophet attained martyrdom in that month. He is regarded by the Sufis as the first martyr of love (for God). Secondly, the langar or free kitchen played a significant role in the institutionalisation of Sufi rituals. Muharram is celebrated by the Shia Muslims with gaiety and fervour. However, the majority of Sufis are Sunnis. Still, they prefer to use Shia symbolism to express their marginalisation by the hegemonic orthodoxy. 
pluralism in Santa Barbara, USA in the year 2010. There I met a lady professor from Cairo who told me that she had never visited the museums or pyramids in Egypt because the items from the age of jahiliya (ignorance of the pre-Islamic Arab world) are preserved there. This professor not only acted as a representative of the hegemonic orthodoxy with her statement but also, interestingly, applied the term jahiliya outside its original context, the geo-cultural frontiers of the Arab peninsula. By contrast, a self-educated Muslim lady of India, Rokeya Sakhawat Hossain, who died in the 1930s and was never directly exposed to western academic institutions, had no problem in celebrating the Indian civilisation of the pre-Islamic era. Does this mean that early modern personalities such as Abdul Haq and Dara Shukoh, or early twentieth century personalities such as Rokeya Sakhawat Hossain, are likely to have been more cosmopolitan, liberal, and modern than their twenty first century counterparts?

\section{References}

Alam, Muzaffar. 2004. The Languages of Political Islam in India. New Delhi: Permanent Black. Aquil, Raziuddin. 2017. Lovers of God: Sufism and the Politics of Islam in Medieval India. New Delhi: Manohar.

Buehler, Arthur F. 2011. Revealed Grace: The Juristic Sufism of Ahmad Sirhindi (1564-1624). Louisville, Kentucky: Fons Vitae.

Chandra, Satish. 1996. Historiography, Religion And State In Medieval India. New Delhi: Har Anand.

De, Amalendu. 1983. 'Nabachetanar Dui Agrapathik Dara Shukoh O Rammohun Roy'. In Rammohun Swaran (in Bengali), eds. Dilip Kumar Biswas and Pratul Chandra Gupta. Kolkata: Raja Rammohun Roy Smritiraksha Samiti, 292-308.

De, Amalendu. 2004. 'Theological Discourses in Indian History', Presidential Address, 2003-2004, The Asiatic Society, Kolkata.1-15.

Dehlavi, Abdul Haq Muhaddis. 1605 (?). Akhbarul Akhiyar [A Sixteenth Century Persian Manuscript apparently completed in 1605, Kolkata: The Asiatic Society, 1863].

Dey, Amit. 1996. Sufism in India. Kolkata: Ratna Prakashan.

Dey, Amit. 2006. The Image of the Prophet in Bengali Muslim Piety; 1850-1947. Kolkata: Readers Service.

Hanif, N. 2000. Biographical Encyclopaedia of Sufis: South Asia. New Delhi: Sarup and Sons. Hasrat, Bikrama J. 1979. Dara Shikuh: Life And Works. New Delhi: Munshiram Manoharlal Publishers Private Limited.

Hughes, Thomas P. 1999. Dictionary of Islam. New Delhi: Munshiram Manoharlal Publishers Private Limited.

Nurul Hasan, Saiyid. 2005. Religion, State and Society in Medieval India. ed. Satish Chandra. New Delhi: Oxford University Press.

Qalandar, Hamid. 1356. Khayrul Majalis [Fourteenth Century Persian Manuscript on Sufism, ed. K. A. Nizami, Aligarh: Muslim University, 1959]. 
Rizvi, Saiyid Athar Abbas. 1986. A History of Sufism in India, Vol. 1. New Delhi: Munshiram Manoharlal Publishers Private Limited.

Robinson, Francis. 2001. The Ulama of Farangi Mahall and Islamic Culture in South Asia. New Delhi: Permanent Black.

Said, Edward. 1993. Culture And Imperialism. London: Chatto and Windus.

Shackle, Christopher (ed. and trans.). 2015. Sufi Lyrics: Bullhe Shah. New Delhi: Murty Classical Library of India.

Schimmel, Annemarie. 1975. Mystical Dimensions of Islam. North Carolina: University of North Carolina Press.

Shukoh, Dara. 1640 (?). Safinatul Awliya [Persian Manuscript].

Shukoh, Dara. 1654-1655. Majma-ul-Bahrain [Persian Manuscript, edited in the original Persian with English translation, notes, and variants by M. Mahfuz - ul - Haq, Kolkata: The Asiatic Society, first published 1929, reprinted 1982.].

Smith, Margaret. 1928. Rabia The Mystic And Her Fellow Saints in Islam. Cambridge: Cambridge University Press. 
